\title{
Neonatal Hypoglycaemia in Infants of Diabetic Mothers given Sulphonylurea Drugs in Pregnancy
}

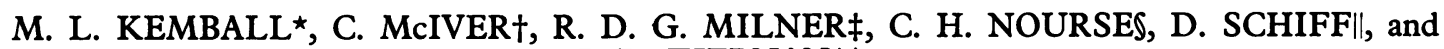 \\ J. R. TIERNAN $\star \star$ \\ From the Boston Lying In Hospital, Boston, Mass., U.S.A.; St. Mary's Hospital, London, and Neonatal Research Unit, \\ Department of Child Health, Hammersmith Hospital, London, U.K., and The M.R.C. Tropical Metabolism Research \\ Unit, Jamaica
}

Kemball, M. L., McIver, C., Milner, R. D. G., Nourse, C. H., Schiff, D., Tiernan, J. R. (1970). Archives of Disease in Childhood, 45, 696. Neonatal hypoglycaemia in infants of diabetic mothers given sulphonylurea drugs in pregnancy. Three infants whose diabetic mothers were given chlorpropamide and one infant whose diabetic mother was given acetohexamide up to the time of delivery were studied in the neonatal period because each became severely hypoglycaemic. The sulphonylurea drugs given to the mother crossed the placenta, and fetal plasma concentrations were in the therapeutic range for adults with diabetes mellitus. Each baby had severe hyperinsulinaemia resulting in profound hypoglycaemia. These acutely ill infants needed vigorous and prolonged treatment to correct the hypoglycaemia. In two infants exchange transfusion was performed to remove the drug. These sulphonylurea drugs should not be used to control diabetes mellitus in pregnancy.

In a three-year period, in different hospitals, four infants were born to diabetic mothers who had been treated with oral sulphonylurea drugs during pregnancy. Each baby had prolonged symptomatic hypoglycaemia in the neonatal period associated with hyperinsulinism. The clinical management and laboratory findings of these babies are presented in detail because they provide direct evidence for an iatrogenic disease caused by the effect on the fetus of sulphonylurea drugs given to the mother.

\section{Patients and Methods}

Since these studies were not planned collaboratively there was variation in the clinical management, laboratory investigations, and therapy between cases. There was, however, sufficient uniformity in some of the

Received 15 April 1970.

^Department of Child Health, Hammersmith Hospital, London W.12.

tDepartment of Medicine, University Hospital, University of the West Indies, Kingston 7, Jamaica.

$¥$ R. D. G. Milner, Department of Child Health, St. Mary's Hospital, Whitworth Park, Manchester 13.

§C. H. Nourse, Ipswich and East Suffolk Hospital, Ipswich, Suffolk.

IID. Schiff, Montreal Children's Hospital, Montreal 25, Quebec, Canada.

$\star \star J$. R. Tiernan, Department of Child Health, University of Queensland, St. Lucia, Queensland, Australia. investigations to allow direct comparison to be made between the infants., The clinical and laboratory data of each baby are presented in the case histories.

Blood or plasma glucose levels were measured by a glucose oxidase method and values of $20 \mathrm{mg} . / 100 \mathrm{ml}$. or less were considered to be hypoglycaemic. Serum or plasma insulin levels were measured by immunoassay (Hales and Randle, 1963; Morgan and Lazarow, 1963; Tiernan, Kemball, and Soeldner, 1968). Human insulin standards were used in Cases 1, 2, and 3; a beef insulin standard with a non-discriminatory antibody was used in Case 4. Urinary immunoreactive insulin was measured in Case 3 (Rubenstein et al., 1967). No mother had received insulin before the birth of the baby reported in this study. Plasma levels of chlorpropamide were measured according to Toolan and Wagner (1959) and acetohexamide and its metabolite hydroxyhexamide according to Spingler (1957).

All intravenous or intra-arterial glucose tolerance tests (GTT) were performed by giving glucose $0.5 \mathrm{~g} . / \mathrm{kg}$. in one to two minutes. Blood samples were taken before and at various times in the subsequent hour. The glucose disappearance constant $\left(K_{t}\right)$ was calculated (Greville, 1943) and is expressed throughout as percentage per minute. In the oral leucine tolerance test performed in Case $3 \mathrm{~L}$-leucine $(120 \mathrm{mg}$. $/ \mathrm{kg}$.) was given by gavage during continuous slow intragastric infusion of glucose $1.1 \mathrm{~g} . / \mathrm{kg}$. per hour (Bower, Rayner, and Stimmler, 1967). 


\section{Case Histories}

Case 1. A male infant born on 21 January 1967 at the Lying In Hospital, Boston, to a 32-year-old Negro woman who had gestational diabetes mellitus. The mother's blood glucose levels were fairly well controlled (highest recorded level-190 mg./100 ml.) on acetohexamide (Dymelor) treatment, throughout her entire pregnancy. She received acetohexamide $1000 \mathrm{mg}$. per day for the 3 days immediately before spontaneous vaginal delivery at 36 weeks' gestation. The infant weighed $4200 \mathrm{~g}$. (over 90th centile) and was well apart from the obese, florid appearance characteristic of some infants of diabetic mothers (Farquhar, 1959). At 1 and at 3 hours of age blood glucose levels were $9 \mathrm{mg} . / 100 \mathrm{ml}$. At 7 hours, when the blood glucose level was $15 \mathrm{mg}$./ $100 \mathrm{ml}$., he developed generalized convulsions. Treatment was started by the injection of glucose $0.5 \mathrm{~g} . / \mathrm{kg}$. into the umbilical artery over a 2-minute period. Blood glucose and serum insulin levels were measured beforehand and during the next 30 minutes. The glucose disappearance rate was abnormally fast (Table I). At 10 hours of age the serum level of acetohexamide was $4.4 \mathrm{mg}$. $/ 100 \mathrm{ml}$. and its actively hypoglycaemic metabolite hydroxyhexamide $5.4 \mathrm{mg}$. $/ 100 \mathrm{ml}$. The acetohexamide level was within the adult therapeutic range of 2.1-5.6 mg. $/ 100 \mathrm{ml}$. (Sheldon, Anderson, and Stoner, 1965). Despite the subsequent infusion of large amounts of glucose, hypoglycaemic blood glucose levels were recorded on five occasions in the first two days of life. Artificial milk feeds were started on the third day of life but intravenous glucose could not be discontinued until the fifth day. A second parenteral
GTT via a peripheral vein was performed on the sixth day. Glucose disappearance was slower than before but still abnormally fast (Table II). Clinical progress at this time was normal however and continued to be so until the age of 9 months when he was last seen.

The mother subsequently completed a normal pregnancy in which her diabetes was controlled with Lente insulin. A male infant weighing $3400 \mathrm{~g}$. was delivered vaginally at 40 weeks and, apart from transient hypoglycaemia at the age of $\mathbf{2}$ hours accompanied by tachypnoea and 'jitteriness', was subsequently normal (Dr. K. Emerson, Jr., personal communication).

Case 2. A female infant born on 29 November 1966 at St. Mary's Hospital, London, to an obese Negro woman with diabetes mellitus. The mother had had five normal deliveries before 1961 followed by an abortion and then a stillborn infant weighing $6000 \mathrm{~g}$. In the post-partum period an oral GTT had not been diagnostic of diabetes mellitus.

During the 34th week of the present pregnancy her GTT was found to be abnormal and she was given $100 \mathrm{mg}$. chlorpromamide daily for the 2 weeks until vertex vaginal delivery occurred at 36 weeks' gestation. Random blood glucose levels during this period were 60,138 , and $85 \mathrm{mg} . / 100 \mathrm{ml}$. The baby who weighed $4100 \mathrm{~g}$. (over 90 th centile) had the severe limb deformities of arthrogryposis and a small cleft in the soft palate. She was severely asphyxiated at birth and required intubation and positive pressure ventilation for 15 minutes before she started to breathe. At this stage she was given $50 \mathrm{mg}$. hydrocortisone intramuscularly and

TABLE I

First Glucose Tolerance Test

\begin{tabular}{|c|c|c|c|c|c|c|c|c|}
\hline Clinical Details & \multicolumn{2}{|c|}{ Case 1} & \multicolumn{2}{|c|}{ Case 2} & \multicolumn{2}{|c|}{ Case 3} & \multicolumn{2}{|c|}{ Case 4} \\
\hline $\begin{array}{l}\text { Age (hr.) } \\
\text { Previous intake } \\
\text { Glucose } 0.5 \mathrm{~g} . / \mathrm{kg} \text {. } \\
\text { given via- } \\
\text { Blood samples taken } \\
\text { via- }\end{array}$ & \multicolumn{2}{|c|}{$\begin{array}{l}7 \\
\text { None } \\
\text { Umbilical artery } \\
\text { Umbilical artery }\end{array}$} & \multicolumn{2}{|c|}{$\begin{array}{l}35 \\
\text { i.v. glucose } 3 \mathrm{~g} \cdot / \mathrm{hr} \text {. } \\
\text { stopped } 20 \mathrm{~min} \text {. } \\
\text { before test } \\
\text { Umbilical vein } \\
\text { Umbilical vein }\end{array}$} & \multicolumn{2}{|c|}{$\begin{array}{l}4.5 \\
10 \mathrm{ml} . \text { breast milk } \\
\text { at } 1 \text { and } 2 \mathrm{hr} .0 \\
\text { Umbilical vein } \\
\text { Umbilical artery }\end{array}$} & \multicolumn{2}{|c|}{$\begin{array}{l}8 \\
\text { None } \\
\text { Umbilical vein } \\
\text { Umbilical vein }\end{array}$} \\
\hline Time (min.) & $\begin{array}{c}\text { Plasma } \\
\text { Glucose } \\
\text { (mg./100 ml.) }\end{array}$ & $\begin{array}{c}\text { Serum } \\
\text { Insulin } \\
(\mu \mathrm{U} / \mathrm{ml} .)\end{array}$ & $\begin{array}{c}\text { Blood } \\
\text { Glucose } \\
\text { (mg./100 ml.) }\end{array}$ & $\begin{array}{c}\text { Serum } \\
\text { Insulin } \\
(\mu \mathrm{U} / \mathrm{ml} .)\end{array}$ & $\begin{array}{c}\text { Blood } \\
\text { Glucose } \\
(\mathrm{mg} \cdot / 100 \mathrm{ml} .)\end{array}$ & $\underset{\substack{\text { Snsulin } \\
(\mu \mathrm{U} / \mathrm{ml} .)}}{\underset{n}{\text { Serum }}}$ & $\begin{array}{c}\text { Plasma } \\
\text { Glucose } \\
\text { (mg. } / 100 \mathrm{ml} .)\end{array}$ & $\begin{array}{c}\text { Plasma } \\
\text { Insulin } \\
(\mu \mathrm{U} / \mathrm{ml} .)\end{array}$ \\
\hline $\begin{array}{lr}\text { Before injection } & 0 \\
\text { After injection } & 1 \\
& 3 \\
& 5 \\
& 10 \\
& 12 \\
& 20 \\
& 30 \\
& 40 \\
& 50 \\
& 60\end{array}$ & $\begin{array}{r}15 \\
207 \\
181 \\
141 \\
113 \\
\frac{75}{45} \\
- \\
-\end{array}$ & $\begin{array}{r}240 \\
95 \\
265 \\
263 \\
228 \\
\overline{297} \\
- \\
- \\
-\end{array}$ & $\begin{array}{r}<5 \\
250 \\
155 \\
132 \\
95 \\
51 \\
30 \\
12 \\
7 \\
<5\end{array}$ & 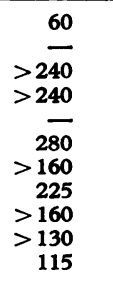 & $\begin{array}{r}13 \\
183 \\
160 \\
139 \\
98 \\
70 \\
70 \\
41 \\
21 \\
13 \\
8\end{array}$ & $\begin{array}{l}36 \\
71 \\
62 \\
72 \\
57 \\
54 \\
40 \\
42 \\
\end{array}$ & $\frac{37}{\frac{427}{223}} \frac{-}{154}$ & $\frac{101}{\overline{119}} \overline{\frac{94}{91}}$ \\
\hline $\begin{array}{l}\text { Glucose } \mathbf{K}_{\mathrm{t}} \\
(\% \text { per min.) }\end{array}$ & $4 \cdot 7$ & & $7 \cdot 0$ & & $5 \cdot 0$ & & $2 \cdot 7$ & \\
\hline
\end{tabular}


TABLE II

Subsequent Glucose Tolerance Tests

\begin{tabular}{|c|c|c|c|c|c|c|c|c|c|}
\hline \multicolumn{2}{|l|}{ Clinical details } & \multicolumn{2}{|c|}{ Case 1} & \multicolumn{2}{|c|}{ Case 3} & \multicolumn{4}{|c|}{ Case 4} \\
\hline \multicolumn{2}{|l|}{$\begin{array}{l}\text { Age } \\
\text { Previous intake } \\
\text { Glucose } 0.5 \mathrm{~g} / \mathrm{kg} . \\
\text { given via- } \\
\text { Blood samples } \\
\text { taken via- }\end{array}$} & \multicolumn{2}{|c|}{$\begin{array}{l}6 \text { days } \\
\text { Fed } 2 \mathrm{hr} \text {. previously } \\
\text { Peripheral vein } \\
\text { Peripheral vein }\end{array}$} & \multicolumn{2}{|c|}{$\begin{array}{l}55 \text { hours } \\
\text { i.v. hexose infusion } \\
\text { stopped at start of } \\
\text { test; } 10 \mathrm{ml} \text {. breast } \\
\text { milk } 2 \mathrm{hr} \text {. previously } \\
\text { Umbilical vein } \\
\text { Umbilical artery }\end{array}$} & \multicolumn{2}{|c|}{$\begin{array}{l}30 \text { hours } \\
10 \% \text { i.v. glucose } 10 \mathrm{ml} \text {. } \\
\text { per hr. stopped immedi- } \\
\text { ately before test } \\
\text { Umbilical vein } \\
\text { Umbilical vein }\end{array}$} & \multicolumn{2}{|c|}{$\begin{array}{l}54 \text { hours } \\
\text { Fed } 3 \mathrm{hr} \text {. previously } \\
\text { Umbilical vein } \\
\text { Umbilical vein }\end{array}$} \\
\hline Time (min.) & & $\begin{array}{c}\text { Blood } \\
\text { Glucose } \\
\text { (mg./100 ml.) }\end{array}$ & $\begin{array}{c}\text { Serum } \\
\text { Insulin } \\
(\mu \mathrm{U} / \mathrm{ml} .)\end{array}$ & $\left|\begin{array}{c}\text { Blood } \\
\text { Glucose } \\
\text { (mg./100 ml.) }\end{array}\right|$ & $\begin{array}{c}\text { Serum } \\
\text { Insulin } \\
(\mu \mathrm{U} / \mathrm{ml} .)\end{array}$ & $\mid \begin{array}{c}\text { Plasma } \\
\text { Glucose } \\
\text { (mg./100 ml. })\end{array}$ & $\begin{array}{c}\text { Plasma } \\
\text { Insulin } \\
(\mu \mathrm{U} / \mathrm{ml} .)\end{array}$ & $\begin{array}{c}\text { Plasma } \\
\text { Glucose } \\
\text { (mg./100 ml.) }\end{array}$ & $\begin{array}{c}\text { Plasma } \\
\text { Insulin } \\
(\mu \mathrm{U} / \mathrm{ml} .)\end{array}$ \\
\hline $\begin{array}{l}\text { Before injection } \\
\text { After injection }\end{array}$ & $\begin{array}{r}0 \\
1 \\
2 \\
3 \\
5 \\
10 \\
20 \\
30 \\
40 \\
50 \\
60 \\
120 \\
180\end{array}$ & $\begin{array}{l}\frac{65}{180} \\
\frac{158}{140} \\
\frac{105}{-} \\
\frac{42}{=} \\
=\end{array}$ & $\begin{array}{l}\frac{48}{290} \\
\frac{219}{158} \\
90 \\
\overline{-} \\
\frac{25}{=} \\
=\end{array}$ & $\begin{array}{r}38 \\
225 \\
208 \\
190 \\
140 \\
50 \\
17 \\
7 \\
5 \\
= \\
=\end{array}$ & $\begin{array}{r}23 \\
200 \\
210 \\
155 \\
123 \\
\frac{57}{57} \\
13 \\
13 \\
= \\
=\end{array}$ & $\begin{array}{l}\frac{10}{\bar{Z}} \\
\frac{227}{\overline{125}} \\
\overline{49} \\
\overline{-} \\
\overline{14} \\
18 \\
25\end{array}$ & $\begin{array}{r}50 \\
\overline{1} \\
1015 \\
\frac{561}{-} \\
254 \\
\frac{-}{70} \\
34 \\
49\end{array}$ & $\begin{array}{l}\frac{33}{7} \\
\frac{394}{137} \\
\frac{84}{\overline{84}} \\
\overline{-} \\
34 \\
43\end{array}$ & $\begin{array}{l}\frac{77}{7} \\
440 \\
\frac{367}{7} \\
\frac{190}{-} \\
\frac{7}{63} \\
48 \\
55\end{array}$ \\
\hline $\begin{array}{l}\text { Glucose } \mathbf{K}_{\mathbf{t}} \\
(\% \text { per } \min .)\end{array}$ & & 2.9 & & $10 \cdot 0$ & & $4 \cdot 4$ & & $5 \cdot 5$ & \\
\hline
\end{tabular}

$10 \%$ glucose via an umbilical venous catheter. Later in the first and second days of life, while receiving intravenous glucose she was found to be hypoglycaemic. An intravenous GTT at the age of 35 hours revealed an undetectable level of glucose in the initial sample and a very rapid fall to hypoglycaemic levels within $\mathbf{4 0}$ minutes of the injection (Table I). The serum insulin level was high at the start of the test and rose further after the glucose injection. The serum chlorpropamide level during the test was $2 \cdot 1 \mathrm{mg}$. $/ 100 \mathrm{ml}$., near the therapeutic range for adults, $3 \cdot 0-14.0 \mathrm{mg} . / 100 \mathrm{ml}$. (Sheldon et al., 1965). Despite an increased intravenous glucose intake to provide $100 \mathrm{cal} . \mathrm{kg}$. per 24 hours, a prednisone dose of $24 \mathrm{mg}$. per 24 hours and the administration of glucagon 6 hourly, she remained hypoglycaemic and it was four days before her drip could be discontinued. At 10 days, reduction in the dose of prednisone and glucagon was associated with apnoeic spells during which blood glucose levels of 11 and $15 \mathrm{mg} . / 100 \mathrm{ml}$. were recorded. On the eleventh day chlorpropamide was still detectable in the blood at a concentration of $0.5 \mathrm{mg} .100 \mathrm{ml}$. All treatment was discontinued by the age of 4 weeks and the baby remained well until, at 5 weeks, she died suddenly following inhalation of vomit. At necropsy the weight of the heart and liver were increased. Most of the islets of Langerhans were normal, but a few in the tail of the pancreas were hypertrophied. The brain showed slight ventricular dilatation with small patches of periventricular leucomalacia. In the white matter of the cerebellum, brainstem, and spinal cord there was obvious fibrous gliosis. The nerve cells were not grossly affected. It was uncertain whether these changes resulted from birth asphyxia or postnatal hypoglycaemia (Anderson, Milner, and Strich, 1967).

Case 3. A male infant was born on 27 December 1966 at Hammersmith Hospital, London, to a 25-yearold Caucasian woman with diabetes mellitus. The mother had had a normal pregnancy in 1960 and had been found to have diabetes in 1965 .

During the present pregnancy, which was entirely normal otherwise, she received $250 \mathrm{mg}$. chlorpropamide daily from 31 weeks' gestation until 24 hours before delivery at 38 weeks. Diabetic control had been excellent, mean blood glucose during the last trimester being $98 \mathrm{mg} . / 100 \mathrm{ml}$. The baby was born by spontaneous vertex delivery, cried, and breathed at once and had a florid appearance. Birthweight $4260 \mathrm{~g}$. (90th centile). Despite hourly feeds of $10 \mathrm{ml}$. breast milk, blood glucose levels in the first four hours of life were all $13 \mathrm{mg}$. $100 \mathrm{ml}$. or less. At $4 \frac{1}{2}$ hours an umbilical intravenous GTT was performed. Blood glucose levels before and at 50 and 60 minutes after the glucose injection were in the hypoglycaemic range (Table I). At 10 hours of age the serum chlorpropamide level was $1.8 \mathrm{mg} . / 100 \mathrm{ml}$. Treatment consisted of the intravenous administration of a mixture of $10 \%$ glucose, $10 \%$ fructose, and $10 \%$ galatose. Infusion at the rate of $85 \mathrm{ml} . / \mathrm{kg}$. per 24 hours which provided $100 \mathrm{cal}$. $/ \mathrm{kg}$. per 24 hours was needed to prevent hypoglycaemia. At 37 hours an exchange transfusion was performed during which a total of $3.7 \mathrm{mg}$. chlorpropamide were removed from the baby. This caused a fall in the serum chlorpropamide level 
from 1.1 to $0.5 \mathrm{mg} . / 100 \mathrm{ml}$. A second umbilical intravenous GTT revealed very high serum insulin levels and a faster glucose disappearance than before (Table II). Most remarkable of all were the 24-hour urinary insulin levels for the first two days of life. At 4240 and $954 \mu \mathrm{U} / \mathrm{mg}$. creatinine, respectively, these insulin levels were more than 100 times greater than those measured in infants of diabetic mothers treated with diet or insulin during pregnancy (Schiff, 1968).

Because of the possibility that exposure to chlorpropamide during fetal life might have caused leucinesensitive hyperinsulinism as occurs in adults (Fajans et al., 1963), protein-containing foods were excluded from the infant's diet. He was fed on a mixture of glucose and arachis oil, and by the fifth day it was possible to stop intravenous therapy. Most blood glucose levels were in the normal range thereafter, but occasional values of less than $20 \mathrm{mg} / 100 \mathrm{ml}$. were recorded in the following three weeks. During the same period the urinary insulin excretion fell to low levels, $12 \cdot 5 \mu \mathrm{U} / \mathrm{mg}$. creatinine (Lowy and Schiff, 1968). At 19 days, protein $1 \mathrm{~g} . / \mathrm{kg}$. per 24 hours was introduced into the diet without the recurrence of symptoms though the urinary insulin levels rose to 108 and $323 \mu \mathrm{U} / \mathrm{mg}$. creatinine. An oral leucine tolerance test was performed at the age of 4 weeks, 7 hours after the last milk feed. There was an obvious rise in serum insulin levels after the leucine load, but no fall in the blood glucose level (Table III). The baby was then given normal feeds and progressed well. At 2 years 10 months of age his physical and mental development seemed normal.

Case 4. A male infant was born on 9 June 1969 at the University Hospital of the West Indies, Jamaica, to a 33-year-old Negro woman who had diabetes mellitus. The mother had had 8 live births and 1 stillbirth previously; 2 of the infants had died in the neonatal period. Diabetes mellitus had been diagnosed in 1965, following the birth of an infant weighing $4580 \mathrm{~g}$.

During the present pregnancy she received $250 \mathrm{mg}$. chlorpropamide daily from the 22 nd week of gestation until delivery. The baby was born at 36 weeks, by
TABLE III

Oral Leucine Tolerance Test in Case 3 at 4 Weeks

\begin{tabular}{lr|c|c}
\hline \multicolumn{2}{c|}{ Time (min.) } & $\begin{array}{c}\text { Blood Glucose } \\
(\mathrm{mg} . / 100 \mathrm{ml} .)\end{array}$ & $\begin{array}{c}\text { Serum Insulin } \\
(\mu \mathrm{U} / \mathrm{ml} .)\end{array}$ \\
\hline Before leucine & 75 & 89 & 24 \\
& 45 & 105 & 37 \\
After leucine & 0 & 70 & 35 \\
(120 mg./kg.) & 30 & 103 & 41 \\
& 45 & 103 & 81 \\
& 60 & 105 & 105 \\
& & 115 & 115 \\
\hline
\end{tabular}

forceps, because of a prolonged second stage with fetal distress (heart rate more than 150/minute intermittently for approximately 5 hours). Birthweight $4.0 \mathrm{~kg}$. (over 90th centile). At birth the infant had an Apgar score of 4, moderate cephalic moulding, and a right Erb's paisy. During the first hours of life he was cyanosed when nursed in air and had an apnoeic attack. At 8 hours of age a GTT (Table I) showed an abnormally fast disappearance of glucose and high plasma insulin levels. The plasma chlorpropamide level at this time was $2.8 \mathrm{mg} .100 \mathrm{ml}$. He was then given $10 \mathrm{ml}$. $10 \%$ glucose/hour for 20 hours by the umbilical vein. Immediately the infusion was stopped the GTT was repeated (Table II). Because the glucose disappearance rate was very rapid and the plasma chlorpropamide level was $2.9 \mathrm{mg} . / 100 \mathrm{ml}$. an exchange transfusion was performed at the age of 36 hours. $580 \mathrm{ml}$. blood was removed and $610 \mathrm{ml}$. fresh blood preserved with glucose and citrate was infused in $20 \mathrm{ml}$. aliquots. Measurements of plasma insulin and glucose were made on the donor blood and on the blood removed from the baby before and at various times during the transfusion. These measurements were compared with those made under the same condition in 22 exchange transfusions for rhesus incompatibility (Milner and Wright, 1966). Case 4 had a higher insulin response and a smaller rise in plasma glucose than the mean change in the earlier study (Table IV). Chlorpropamide $13.3 \mathrm{mg}$. , was

\section{TABLE IV}

Plasma Glucose, Insulin, and Chlorpropamide Levels During Exchange Transfusion in Case 4 Compared with 22 Transfusions for Rhesus Incompatibility

\begin{tabular}{|c|c|c|c|c|c|}
\hline & \multicolumn{3}{|c|}{ Case 4} & \multicolumn{2}{|c|}{$\begin{array}{c}\text { Rhesus-Exchanges }{ }^{\star} \\
\text { (mean } \pm S E \text { of mean }(n=22)\end{array}$} \\
\hline & $\begin{array}{l}\text { Plasma Glucose } \\
\text { (mg./100 ml.) }\end{array}$ & $\begin{array}{l}\text { Plasma Insulin } \\
(\mu \mathrm{U} / \mathrm{ml} .)\end{array}$ & $\begin{array}{c}\text { Plasma } \\
\text { Chlorpropamide } \\
(\mathrm{mg} . / 100 \mathrm{ml} .)\end{array}$ & $\begin{array}{l}\text { Plasma Glucose } \\
\text { (mg./100 ml.) }\end{array}$ & $\begin{array}{l}\text { Plasma Insulin } \\
\text { ( } \mu \mathrm{U} / \mathrm{ml} .)\end{array}$ \\
\hline 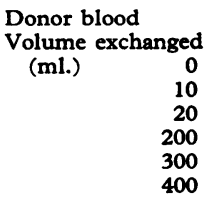 & $\begin{array}{l}271 \\
33 \\
48 \\
46 \\
64 \\
79 \\
77\end{array}$ & $\begin{array}{r}34 \\
\\
67 \\
64 \\
86 \\
135 \\
148 \\
149\end{array}$ & $\begin{array}{l}- \\
2 \cdot 9 \\
2 \cdot 6 \\
2 \cdot 5 \\
2 \cdot 4 \\
2 \cdot 3 \\
1 \cdot 9\end{array}$ & $\begin{array}{r}61 \pm 7 \\
90 \pm 5 \\
101 \pm 5 \\
144 \pm 5 \\
158 \pm 6 \\
165 \pm 6\end{array}$ & $\begin{array}{l}36 \pm 3 \\
36 \pm 4 \\
39 \pm 4 \\
86 \pm 10 \\
88 \pm 10 \\
88 \pm 10\end{array}$ \\
\hline
\end{tabular}

*Data from Milner and Wright (1966). 
removed by the exchange transfusion. Despite this, the plasma concentration only fell from 2.9 to $1.9 \mathrm{mg}$./ $100 \mathrm{ml}$. from the start to the $400 \mathrm{ml}$. point in the transfusion, indicating that some of the drug was stored extravascularly.

After the transfusion the baby was fed with $40 \mathrm{ml}$. half strength full-cream milk 3-hourly, and showed no further clinical abnormality apart from one spell of 'jitteriness'. A third GTT performed at 54 hours still showed, but to lesser degree, the abnormalities noted in the second test (Table II). The plasma chlorpropamide level was $1.6 \mathrm{mg} . / 100 \mathrm{ml}$. Feeds were subsequently dissolved in $10 \%$ fructose and the baby became less drowsy and lethargic. He remained clinically normal thereafter and fructose supplements were discontinued on the sixth day.

\section{Discussion}

Each of the 4 infants reported here had been exposed to a sulphonylurea drug for the last two or more weeks in utero and was born with significant levels of the drug in the circulation. Each had protracted symptomatic hypoglycaemia due to obvious hyperinsulinism in the immediate postnatal days. Prolonged intravenous treatment with glucose was of prime importance in treatment. The addition of fructose to the diet of one infant and the exclusion of leucine from the diet of another infant both appeared to be important measures in diminishing the stimuli to insulin secretion. In 2 infants exchange transfusion removed appreciable amounts of chlorpropamide from both intra- and extravascular pools and was thought to have shortened the infants' illness.

It is known that tolbutamide and chlorpropamide cross the human placenta to reach therapeutic levels in the newborn infant (Miller, Wishinsky, and Thompson, 1962; Zucker and Simon, 1968). Our findings are confirmatory for chlorpropamide, and show that transplacental passage also occurs with acetohexamide. Infants of diabetic women who have been treated with insulin or diet alone may have hypertrophy of the islets of Langerhans (Cardell, 1953). As sulphonylurea drugs are also known to stimulate $\beta$-cell hyperplasia, they may be expected to augment the effects of maternal diabetes on fetal islet cell development in this respect. Moreover, in the first days of life, when hepatic drug metabolism is immature, an obvious prolongation of half-life has been demonstrated for tolbutamide (Nitowsky, Matz, and Berzofsky, 1966). For chlorpropamide, which even in adults has a half-life of 36 hours (Kelly and Johnson, 1959), five times that of tolbutamide or acetohexamide, such a delay in metabolism is likely to be particularly dangerous. The presence of measurable levels of chlorpropamide in the blood of Case 2 as late as the 11 th day of life appears to confirm this prediction. Thus, sulphonylurea drugs given during pregnancy may not only act by stimulating $\beta$-cell hyperplasia in utero, but may also have a prolonged pharmacological effect postnatally.

In the first few hours after birth most infants of insulin-treated diabetic mothers have profound but transient and asymptomatic hypoglycaemia (Cornblath and Schwartz, 1966; Farquhar and Isles, 1968). The 4 infants presented here differed from them not only in the prolonged duration of hypoglycaemia but in the presence of severe symptoms. Though severe birth asphyxia may result in reduced hepatic carbohydrate stores and hypoglycaemia in the immediate postnatal period (Shelley and Neligan, 1966) and may, therefore, have contributed to the disturbance in Cases 2 and 4, it cannot be implicated at any stage in Cases 1 and 3, nor in the prolonged illness of any of the 4 infants. In them the major cause of hypoglycaemia was undoubtedly increased secretion of insulin.

Immunoreactive insulin levels cannot be measured in the serum of infants of diabetic mothers treated with insulin because circulating antibodies to the exogenous hormone interfere with the assay system. Thus, the serum levels of insulin in our 4 infants can only be compared with those infants of diabetic mothers controlled by diet alone. None of the 11 such infants previously studied by similar GTT techniques (Tiernan, Kemball, and Smith, 1968) showed the sustained hyperinsulinism in the presence of hypoglycaemia which was such a distinctly abnormal feature of the 4 infants described here. Anti-insulin antibodies are not excreted in the urine of infants of insulin-treated mothers. The urine insulin levels of a group of such infants (Schiff, 1968) are therefore a valid comparison for the remarkably high values found in Case 3. Thus, these 4 infants who were chronically exposed to sulphonylurea drugs showed evidence of increased and inappropriate insulin secretion both when their serum levels were compared with those of infants of diet-controlled mothers and when urine levels were compared with those of infants of insulincontrolled mothers.

Studies of the effects of sulphonylurea drugs on the outcome of diabetic pregnancy have differed in their conclusions and have been reviewed by Adam and Schwartz (1968). Some centres have shown no increase in perinatal mortality and morbidity (Dolger, Bookman, and Nechemias, 1962; Douglas and Richards, 1967; Sutherland et al., 1970). Others have expressed a cautious view (Malins et al., 1964), and finally one study has shown a rise in perinatal mortality in infants of chlorpropamide- 
treated mothers (Jackson et al., 1962). In addition there have been several isolated reports of severe hypoglycaemic illness in infants of mothers given tolbutamide (Nitowsky et al., 1966, and personal communication) and chlorpropamide (Zucker and Simon, 1968; Farquhar and Isles, 1968). It remains a mystery why some infants of mothers given sulphonylurea drugs are severely affected while others appear to be healthy.

Symptomatic hypoglycaemia of the newborn carries a considerable risk of death or severe cerebral damage in survivors (Haworth et al., 1963; Brown and Wallis, 1963; Anderson et al., 1967). Till there is some means of detecting in advance those infants who would be adversely affected in this way, it seems to us that the grave hazards of sulphonylurea treatment are such that these drugs should be avoided in the obstetric management of diabetic women.

We are grateful to Professors Back, Oppé, Smith, and Tizard who allowed us to study patients in their care, to Dr. D. Grant for estimation of serum insulin levels of Case 2; to Dr. C. Lowy for estimation of serum and urine insulin levels in Case 3; and to Pfizer and Co. for support and the estimation of plasma chlorpropamide levels in Case 4. Dr. S. J. Strich kindly performed the necropsy on the brain of Case 2. M.L.K., J.R.T., and C.H.N. were Research Fellows in Paediatrics, Harvard Medical School (U.S.P.H.S. grants H.D.-00050 and 05481), and M.L.K. was subsequently Fellow in Medicine, Boston Hospital for Women (grant FR-05481). The work was also supported by a grant from the Association for the Aid of Crippled Children, New York. D.S. was Research Fellow on a MacLoughlin Travelling Fellowship from McGill University at the Neonatal Research Unit, Hammersmith Hospital.

\section{REFERENCES}

Adam, P. A. J., and Schwartz, R. (1968). Diagnosis and treatment: should oral hypoglycemic drugs be used in pediatric and pregnant patients ? Pediatrics, 42, 819.

Anderson, J. M., Milner, R. D. G., and Strich, S. J. (1967). Effects of neonatal hypoglycaemia on the nervous system: a pathological study. Fournal of Neurology, Neurosurgery and Psychiatry, 30, 295.

Bower, B. D., Rayner, P. H. W., and Stimmler, L. (1967). Leucinesensitive hypoglycaemia treated with diazoxide. Archives of Disease in Childhood, $42,410$.

Brown, R. J. K., and Wallis, P. G. (1963). Hypoglycaemia in the newborn infant. Lancet, $1,1278$.

Cardell, B. S. (1953). Infants of diabetic mothers: a morphological study. Fournal of Obstetrics and Gynaecology of the British Empire, 60, 834.

Cornblath, M., and Schwartz, R. (1966). Disorders of Carbohydrate Metabolism in Infancy, p. 65. Saunders, Philadelphia and London.

Dolger, H., Bookman, J. J., and Nechemias, C. (1962). The diagnostic and therapeutic value of tolbutamide in pregnant diabetics. Diabetes, 11, suppl., 97.

Douglas, C. P., and Richards, R. (1967). Use of chlorpropamide in the treatment of diabetes in pregnancy. Diabetes, 16, 60.
Fajans, S. S., Knopf, R. F., Floyd, J. C., Jr., Power, L., and Conn, J. W. (1963). The experimental induction in man of sensitivity to leucine hypoglycemia. Fournal of Clinical Investigation, 42, 216.

Farquhar, J. W. (1959). The child of the diabetic woman. Archives of Disease in Childhood, 34, 76.

-, and Isles, T. E. (1968). Hypoglycemia in newborn infants of normal and diabetic mothers. South African Medical fournal, 42, 237.

Greville, G. D. (1943). The intravenous glucose tolerance equation. Biochemical fournal, 37, 17.

Hales, C. N., and Randle, P. J. (1963). Immunoassay of insulin with insulin-antibody precipitate. Biochemical fournal, 88, 137.

Haworth, J. C., Coodin, F. J., Finkel, K. C., and Wiedman, M. L. (1963). Hypoglycemia associated with symptoms in the newborn period. Canadian Medical Association fournal, 88, 23.

Jackson, W. P. U., Campbell, G. D., Notelovitz, M., and Blumsohn, D. (1962). Tolbutamide and chlorpropamide during pregnancy in human diabetics. Diabetes, 11, suppl., 98.

Kelly, M. W., and Johnson, P. C. (1959). The comparative pharmacology of tolbutamide, carbutamide, chlorpropamide and metahexamide in man. Metabolism, 8, 596.

Lowy, C., and Schiff, D. (1968). Urinary excretion of insulin in the healthy newborn. Lancet, 1, 225.

Malins, J. M., Cooke, A. M., Pyke, D. A., and Fitzgerald, M. G. (1964). Sulphonylurea drugs in pregnancy. (Correspondence.) British Medical fournal, 2, 187.

Miller, D. I., Wishinsky, H., and Thompson, G. (1962). Transfer of tolbutamide across the human placenta. Diabetes, 11, suppl., 93.

Milner, R. D. G., and Wright, A. D. (1966). Blood glucose, plasma insulin and growth hormone response to hyperglycaemia in the newborn. Clinical Science, 31, 309.

Morgan, C. R., and Lazarow, A. (1963). Immunoassay of insulin: two antibody system. Diabetes, 12, 115.

Nitowsky, H. M., Matz, L., and Berzofsky, J. A. (1966). Studies on oxidative drug metabolism in the full-term newborn infant. Fournal of Pediatrics, 69, 1139.

Rubenstein, A. H., Lowy, C., Welborn, T. A., and Fraser, T. R. (1967). Urine insulin in normal subjects. Metabolism, 16, 234.

Schiff, D (1968). Ph.D. Thesis, University of London.

Sheldon, J., Anderson, J., and Stoner, L. (1965). Serum concentration and urinary excretion of oral sulfonylurea compounds: relation to diabetic control. Diabetes, 14, 361 .

Shelley, H. J., and Neligan, G. A. (1966). Neonatal hypoglycaemia. British Medical Bulletin, 22, 34.

Spingler, H. (1957). UUber eine Möglichkeit zur colorimetrischen Bestimmung von N-(4-Methyl-Benzolsulfonyl)-N-ButylHarnstoff in Serum. Klinische Wochenschrift, 35, 533.

Sutherland, H. W., Bewsher, P. D., Cormack, J. D., and Stowers, J. M. (1970). Evaluation of the use of chlorpropamide in chemical diabetes diagnosed during pregnancy. Diabetologia, 6,65 .

Tiernan, J. R., Kemball, M. L., and Smith, C. A. (1968). Fndogenous insulin secretion in the newborn infant. Abstract, Programme of Society for Pediatric Research. Meeting, Atlantic City, N.F., May 3-4, 1968.

,, and Soeldner, J. S. (1968). A micromodification of the two antibody radioimmunoassay for serum insulin. Fournal of Laboratory and Clinical Medicine, 71, 345.

Toolan, T. J., and Wagner, R. L., Jr., (1959). The physical properties of chlorpropamide and its determination in human serum. Annals of the New York Academy of Sciences, 74, 449.

Zucker, P., and Simon, G. (1968). Prolonged symptomatic neonatal hypoglycemia associated with maternal chlorpropamide therapy. Pediatrics, 42, 824.

Correspondence to Dr. M. L. Kemball, Department of Child Health, Hammersmith Hospital, Du Cane Road, London W.12. 